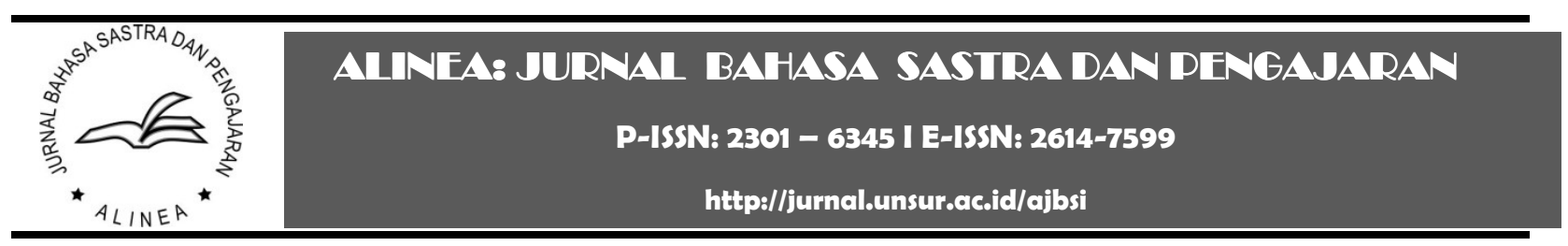

\title{
TINDAK TUTUR DIREKTIF PELATIH DRUM CORPS SABDA KINNARA DRUM CORPS
}

\author{
Adnia Safira \& Asep Purwo Yudi Utomo \\ Universitas Negeri Semarang, Semarang, Indonesia
}

Riwayat artikel:

Dikirim: 22 Mei 2020

Direvisi: 30 Agustus 2020

Diterima: 7 September 2020

Diterbitkan: 30 Oktober 2020

Katakunci:

direktif, tindak tutur

Keywords:

directive, speech act

Alamat surat

adniasafira@students.unnes.ac.id

\begin{abstract}
Abstrak:
Peristiwa tutur satu arah antara pelatih dengan pemain (player) pada pelatihan drum corps di Sabda Kinnara Drum Corps UNNES merupakan hal yang mendasari dilakukannya penelitian. Penelitian dilakukan menggunakan metode deskriptif kualitatif. Data penelitian dikumpulkan dengan metode simak dan metode cakap. Data utama penelitian berupa hasil sadapan terhadap tuturan dua pelatih Sabda Kinnara Drum Corps UNNES divisi Colour Guard (CG) dengan data pendukung berupa hasil wawancara dengan pelatih divisi CG. Objek penelitian ini adalah tindak tutur direktif pelatih drum corps divisi Colour Guard (CG). Dari penelitian ini diperoleh 21 bentuk tindak tutur direktif yang digunakan pelatih SKDCU divisi CG, di antaranya 8 tindak tutur memerintah, 3 tindak tutur memohon, 6 tindak tutur menyarankan, dan 4 tindak tutur menantang.
\end{abstract}

\begin{abstract}
:
The one-way speech from the coach to the players at the drum corps training at Sabda Kinnara Drum Corps UNNES was the basis of the research. The research was conducted using a qualitative descriptive method. The research data were collected using recording and interview. The main data of the research are the results of recording of utterances used by two coaches in Sabda Kinnara Drum Corps UNNES Color Guard (CG) division with supporting data from interviews with the CG division coaches. The object of this research is directive speech act used by coach of Color Guard $(C G)$ drum corps. This research reveals that there are 21 forms of directive speech acts used by the CG division SKDCU coaches, including 8 commanding speech acts, 3 pleading speech acts, 6 suggesting speech acts, and 4 challenging speech acts.
\end{abstract}

\section{PENDAHULUAN}

Berbicara merupakan keterampilan berbahasa yang memegang peranan penting dalam kehidupan sehari-hari, yakni sebagai alat komunikasi. Tarigan (dalam Nawawi dkk. 2017:22) menjabarkan berbicara adalah kemampuan mengucapkan bunyi-bunyi artikulasi atau kata-kata untuk mengekspresikan, menyatakan, serta menyampaikan pikiran, gagasan, dan perasaan. Nurgiyantoro (dalam Nawawi dkk. 2017: 22) menambahkan bahwa berbicara adalah aktivitas berbahasa kedua yang dilakukan manusia dalam kehidupan bahasa setelah mendengarkan.
Dalam menyampaikan hal berupa informasi atau pesan secara langsung kepada mitra tutur, seorang penutur menggunakan keterampilan berbicaranya. Pemilihan kata menjadi faktor penting dalam berbicara agar maksud yang diinginkan penutur sama dengan apa yang diterima mitra tutur. Hal ini penting karena percakapan menjalin sebuah interaksi antara satu individu dengan individu lain dalam bermasyarakat.

Kegiatan belajar mengajar di kelas merupakan salah satu peristiwa tutur yang dapat diamati. Peristiwa tutur tersebut 
melibatkan interaksi antara guru dengan peserta didik. Menurut Putri (2015: 16), tindak tutur yang dilakukan oleh guru dan siswa dapat digunakan sebagai salah satu tolok ukur keefektifan komunikasi dalam pembelajaran. Salah satu indikator keefektifan komunikasi dalam pembelajaran adalah terjadinya komunikasi multiarah, yakni komunikasi yang melibatkan partisipasi siswa dan guru serta siswa dengan siswa lain.

Sama halnya dengan guru, pelatih drum corps menggunakan keterampilan berbicaranya dalam melatih pemain (player). Drum corps merupakan seni memainkan alat musik berbentuk tim yang memiliki ruang lingkup sama dengan marching band. Istilah drum corps masih asing di telinga masyarakat, masyarakat lebih mengenal istilah marching band daripada drum corps. Pada dasarnya, marching band dan drum corps hanya memiliki sedikit perbedaan. Harahap (2012) mengatakan unit drum corps adalah unit yang paling besar dan paling lengkap. Biasanya personilnya berjumlah lebih dari 100 orang. Alat yang digunakan pada dasarnya sama dengan marching band, tetapi yang membedakan adalah jumlah personilnya, lebih banyak dan lebih variatif.

Dalam drum corps, bahasa menjadi faktor penting dalam memberi perintah atau petunjuk khusus pada pelatihan. Istilah-istilah tertentu dalam drum corps dapat memiliki maksud yang berbeda apabila didengar mitra tutur yang tidak memiliki pengetahuan tentang drum corps.

Dalam pelatihan drum corps, interaksi antara pelatih dengan pemain termasuk ke dalam komunikasi satu arah. Peristiwa tutur yang terjadi pada latihan rutin drum corps di Sabda Kinnara Drum Corps UNNES (SKDCU) didominasi oleh tindak tutur yang menuntut player melakukan apa yang dicontohkan pelatih atau disebut dengan tindak tutur direktif. Hal ini menjadi alasan diadakannya penelitian tindak tutur direktif pelatih drum corps.

Tindak tutur merupakan kegiatan berkomunikasi kepada mitra tutur dalam kehidupan sehari-hari, mengakibatkan adanya perbuatan atau tindakan dari sebuah tuturan. Kegiatan berkomunikasi ini tanpa disadari memiliki makna yang membuat orang kedua mampu memberikan jawaban sesuai dengan apa yang harapkan orang pertama. Hal itu merupakan sebuah ketercapaian adanya komunikasi yang baik (Ariyani, 2017: 2).

Yule (2006:92-93) mengklasifikasikan tindak tutur menjadi lima jenis, yaitu deklarasi, representatif, ekspresif, direktif, dan komisif. Tindak tutur direktif merupakan jenis tindak tutur yang dipakai oleh penutur untuk menyuruh orang lain melakukan sesuatu. Jenis tindak tutur ini menyatakan apa yang menjadi keinginan penutur.

Austin (dalam Rustono 1999: 35) mengklasifikasikan tindak tutur menjadi tiga macam, yakni tindakan menginformasikan atau menyatakan sesuatu atau tindak lokusi, tindakan menghendaki mitra tuturnya untuk melakukan sesuatu atau tindak ilokusi, dan tindakan memberikan pengaruh terhadap mitra tutur atau tindak perlokusi.

Austin (1962: 87) mengemukakan tindak tutur direktif adalah tindak tutur yang menimbulkan beberapa efek melalui tindakan sang penyimak, misalnya memesan, memohon, meminta, menyarankan, permintaan dan perintah. Tindak tutur direktif yakni bentuk tindak tutur yang dimaksudkan penuturnya untuk membuat pengaruh agar sang mitra tutur melakukan tindakan tertentu, misalnya saja memesan (ordering), memerintah (commanding), memohon (requesting), menasihati (advising), merekomendasi (recommending) (Adawiyah, 2018: 13). 
Searle (dalam Gunarwan, dalam Elmita, 2013: 140), mengemukakan tindak tutur direktif terbagi atas lima macam, yaitu (a) tindak tutur direktif menyuruh adalah tindak tutur yang dituturkan untuk menyuruh mitra tutur melakukan apa yang penutur ucapkan, (b) tindak tutur direktif memohon adalah tindak tutur yang meminta dengan sopan mitra tutur melakukan sesuatu yang diinginkan penutur, (c) tindak tutur direktif menyarankan adalah tindak tutur yang menyarankan mitra tutur untuk mengerjakan sesuatu hal yang baik menurut penutur untuk mitra tutur dan penutur sendiri, (d) tindak tutur direktif menasihati adalah tuturan yang dilakukan penutur untuk menasihati atau mengingatkan lawan tutur akan sesuatu hal yang akan ia kerjakan, dan (e) tindak tutur direktif menantang adalah tindak tutur untuk memotivasi seseorang agar mau mengerjakan sesuatu yang kita katakan atau tuturkan.

Terdapat beberapa penelitian yang berkaitan secara langsung dari peneliti bahasa, antara lain Ardianto (2013) mengkaji tentang "Tindak Tutur Direktif Guru dalam Wacana Interaksi Kelas Anak Tunarungu". Elmita, dkk. (2013) mengkaji tentang "Tindak Tutur Direktif Guru dalam Proses Belajar Mengajar Di TK Nusa Indah Banuaran Padang", Raditya (2014) mengkaji tentang "Fungsi Tindak Tutur Ilokusi Direktif dalam Film Final Fantasy VII Advent Children: Complete", Prayekti (2015) mengkaji tentang "Tindak Tutur Direktif Guru dalam Pembelajaran Bahasa Indonesia Kelas IX SMP Islam Al Hikmah Jember", Yuliarti, dkk. (2015) mengkaji tentang "Tindak Tutur Direktif dalam Wacana Novel Trilogi Karya Agustinus Wibowo, Arifiany, dkk. (2016) mengkaji tentang pemaknaan "Tindak Tutur Direktif Dalam Komik 'Yowamushi Pedal Chapter 87-93”, Qomariyah (2017) mengkaji tentang "Tindak Tutur Direktif Guru Dalam Pembelajaran Bahasa Arab", Sumarsih (2018) "Strategi dan Fungsi Tindak Tutur
Direktif dalam Poster Pendidikan (Strategy And Function Of Directive Speech Act In Educational Poster)," Waljinah, dkk. (2019) mengkaji tentang "Tindak Tutur Direktif Wacana Berita Online: Kajian Media Pembelajaran Berbasis Teknologi Digital", Ramadhani, dkk. (2019) mengkaji tentang "Analisis Tindak Tutur Direktif Dalam Akun Twitter@sbyudhoyono", dan Cahyani, dkk. (2020) mengkaji tentang "Tindak Tutur Direktif Pedagang Asongan pada Kapal Motor Penyeberangan (KMP) di Pelabuhan Ulee Lheue Banda Aceh.”

Dari penelitian terdahulu tersebut, terdapat persamaan dan perbedaan. Persamaan yang terdapat pada penelitian adalah fokus penelitian. Seluruh penelitian meneliti tentang tindak tutur direktif. Perbedaan penelitian terletak pada objek penelitian. Objek penelitian dari beberapa penelitian bervariatif, antara lain tindak turur direktif guru, tindak tutur direktif film Final Fantasy VII Advent Children: Complete, tindak tutur direktif novel, tindak tutur direktif dalam wacana novel Trilogi karya Agustinus Wibowo, tindak tutur direktif komik pemaknaan tindak tutur direktif dalam Komik "Yowamushi Pedal Chapter 87-93", tindak tutur direktif wacana berita online, tindak tutur direktif dalam akun twitter@sbyudhoyono, dan tindak tutur direktif pedagang asongan.

Bentuk tindak tutur pada penelitian ini diklasifikasikan berdasarkan teori Searle mengenai tindak tutur direktif. Searle mengemukakan tindak tutur direktif terbagi atas lima macam, yaitu (a) tindak tutur direktif menyuruh, (b) tindak tutur direktif memohon, (c) tindak tutur direktif menyarankan, (d) tindak tutur direktif menasihati, dan (e) tindak tutur direktif menantang.

Dengan demikian, penelitian ini dapat dikatakan akan memperkuat penelitian tindak tutur direktif yang mengacu pada teori Searle tentang bentuk tindak tutur direktif. Hal ini 
didukung penelitian yang dilakukan oleh Putri (2016) pada SMA Negeri 15 Padang yang relevan dengan teori Searle. Adapun penelitian yang menggabungkan teori Searle dan Leech, seperti yang dilakukan oleh Mulyani (2015) sehingga bentuk tindak tutur direktif sedikit berbeda menjadi bentuk perintah, permintaan, dan saran. Selain itu, terdapat pula penelitian yang dilakukan oleh Syah (2017) yang memaparkan enam sub-tindak tutur direktif, yaitu mempersilahkan, meminta, bertanya, memerintah, mengajak, dan melarang.

Dari penelitian terdahulu, belum ada yang melakukan penelitian tindak tutur pada pelatih drum corps. Dengan adanya penelitian ini, diharapkan mampu melengkapi penelitian terdahulu mengenai pragmatik terutama dalam kajian tindak tutur direktif.

\section{METODE}

Sudaryanto (dalam Muhammad, 2011: 203) mengemukakan bahwa metode adalah cara yang harus dilaksanakan, sedangkan teknik adalah cara melaksanakan metode. Penelitian ini menggunakan metode deskriptif kualitatif. Penelitian kualitatif memaparkan data lapangan tanpa ada rekayasa. Secara umum, terdapat dua metode untuk menyediakan data, yaitu metode simak dan metode cakap. Metode simak secara praktik dilakukan dengan menyadap menggunakan teknik dasar sadap. Pada penelitian ini, metode simak dengan teknik dasar sadap dijalankan dengan teknik lanjutan teknik simak bebas cakap dan teknik catat. Untuk menjalankan metode simak atau teknik sadap, peneliti menjadi hanya pengamat atau penyimak. Peneliti tidak ikut angkat bicara sama sekali dengan mitranya (Sudaryanto dalam Muhammad, 2011: 208).

Selain itu, peneliti menggunakan teknik catat. Pencatatan dapat dilakukan pada kartu data yang telah disediakan atau akan disediakan. Setelah pencatatan dilakukan, peneliti melakukan klarifikasi atau pengelompokkan (Sudaryanto dalam Muhammad, 2011: 211).

Sudaryanto (dalam Muhammad, 2011: 212) menyatakan bahwa wujud metode cakap atau percakapan dan terjadi kontak antara peneliti dan penutur. Pernyataan ini melibatkan tiga hal, yaitu percakapan dua partisipan, peneliti, dan penutur. Teknik dasar metode ini adalah teknik pancing, yaitu memancing seseorang agar berbicara. Pada penelitian ini, metode cakap dengan teknik dasar pancing dijalankan dengan teknik lanjutan teknik cakap semuka. Peneliti dan narasumber menjadi instrumen penelitian dalam hal ini. Orang yang diwawancarai menjadi sumber informasi, pemberi informasi dan pembantu peneliti untuk memperoleh data yang disediakan untuk dianalisis.

Data utama dari penelitian ini merupakan hasil penyadapan peneliti terhadap tuturan pelatih Sabda Kinnara Drum Corps UNNES (SKDCU) divisi Colour Guard (CG) yang merupakan tindak tutur direktif. Adapun data pendukung berupa hasil wawancara dengan pelatih mengenai istilah-istilah yang digunakan selama latihan berlangsung. Narasumber penelitian ini adalah dua orang pelatih SKDCU divisi Colour Guard (CG). Penelitian dilakukan di kawasan Universitas Negeri Semarang pada Unit Kegiatan Mahasiswa (UKM) Sabda Kinnara Drum Corps UNNES (SKDCU). Objek penelitian ini adalah tindak tutur direktif pelatih drum corps divisi Colour Guard (CG).

\section{HASIL PENELITIAN}

Hasil penelitian ini memuat bentuk tindak tutur direktif sesuai dengan rumusan masalah dan tujuan penelitian yang telah ditentukan. Jumlah tindak tutur direktif yang ditemukan dari dua orang pelatih Sabda Kinnara Drum Corps UNNES (SKDCU) divisi CG pada latihan rutin adalah sebanyak 21 tindak tutur. Ditemukan tuturan pelatih yang diulang dalam jarak waktu tertentu, sehingga tuturan 
yang berulang tidak termasuk dalam hitungan. Setelah dianalisis, diperoleh data tindak tutur direktif dalam empat bentuk, antara lain memerintah, memohon, menyarankan, dan menantang. Tindak tutur memerintah ditemukan sebanyak 8 tindak tutur, tindak tutur memohon sebanyak 3 tindak tutur, tindak tutur menyarankan sebanyak 6 tindak tutur, dan tindak tutur menantang sebanyak 4 tindak tutur.

Setelah data dianalisis, tidak ditemukan adanya tindak tutur direktif bentuk menasihati. Sabda Kinnara Drum Corps UNNES memiliki forum tersendiri untuk mengevaluasi latihan rutin yang sebelumnya sudah dilaksanakan. Selama forum tersebut dilaksanakan, ditemukan adanya tindak tutur direktif bentuk menasihati yang dilakukan pelatih dan pemain. Tetapi, forum tersebut bukanlah bagian dari proses pelatihan. Oleh karena itu, data tindak tutur direktif bentuk menasihati tidak bisa dicantumkan pada penelitian ini.

\section{a. Tindak Tutur Direktif Bentuk Memerintah}

Bach dan Harnish (dalam Ibrahim, dalam Darwis, 2019: 7) mengkategorikan tindak tutur menjadi enam kategori utama, salah satunya yaitu requirement (memerintah, menghendaki, mengkomando, menuntut, mendikte, mengarahkan, menginstruksikan, mengatur, dan mensyaratkan).

Bentuk memerintah merupakan tindak tutur yang paling sering muncul selama proses latihan berlangsung. Bentuk ini digunakan penutur untuk memerintah mitra tutur melakukan suatu hal sesuai kehendak penutur. Pada latihan rutin Sabda Kinnara Drum Corps UNNES (SKDCU) divisi CG, bentuk memerintah digunakan pelatih untuk mendapat respons pemain berupa tindakan atau perilaku yang diinginkan pelatih. Tindak tutur direktif pelatih berbentuk memerintah dalam latihan drum corps di SKDCU divisi CG dapat dilihat pada contoh berikut.

(1) Pelatih: Teman-teman, ambil flag dulu di ruang alat ya.. Lima orang saja yang ke ruang alat.

Pemain: Siap, kak.

(2) Pelatih: Kita akan mempelajari gerakan Butterfly, saya akan mencontohkan gerakannya. Perhatikan baik baik.

Pemain: (sebagian pemain memperhatikan pelatih mencontohkan gerakan dan sebagian pemain menirukan gerakan yang dicontohkan pelatih)

Tindak tutur (1) dan (2) merupakan tindak tutur berbentuk memerintah yang dilakukan oleh pelatih drum corps kepada pemain. Pada tindak tutur (1), pelatih memerintah pemain untuk mengambil bendera (flag) di ruang alat. Tuturan (1) terjadi sebelum memulai proses latihan. Penanda tindak tutur memerintah (1) adalah bentuk 'ambil flag'.

Tindak tutur (2) dilakukan pelatih agar pemain memperhatikan gerakan Butterfly yang akan dicontohkan kepada pemain. Tuturan (2) terjadi sebelum pelatih mencontohkan gerakan Butterfly. Penanda tindak tutur memerintah (2) adalah bentuk 'Perhatikan baik baik'

Pada penelitian sebelumnya yang dilakukan Sumarsih (2018) mengungkapkan bahwa fungsi menyuruh/memerintah terlihat dengan adanya kata suruhan keharusan. Tuturan "Buanglah sampah pada tempatnya" merupakan bentuk tindak tutur direktif memerintah yang ditandai dengan partikel -lah pada kata 'buanglah'. Oleh karena itu, penelitian ini relevan dengan hasil penelitian sebelumnya. 


\section{b. Tindak Tutur Direktif Bentuk Memohon}

Tindak tutur direktif memohon adalah tindak tutur yang dilakukan penutur untuk meminta secara sopan kepada mitra tutur agar melakukan sesuatu yang diinginkan penutur.

Bentuk memohon merupakan tindak tutur yang paling sedikit muncul. Pada latihan rutin SKDCU divisi CG, bentuk memohon digunakan pelatih untuk meminta pemain dengan halus melakukan hal atau sesuatu yang diinginkan pelatih. Tindak tutur direktif pelatih berbentuk memohon dalam latihan drum corps di SKDCU divisi CG dapat dilihat pada contoh berikut.

(3) Pemain: Kak, boleh diulang gerakan Tos-nya?. Saya belum bisa menangkap flag dengan benar.

Pelatih: Saya jelaskan setelah kita istirahat lima menit ya..

Pemain: Baik, kak.

(4) Pelatih: Saya minta, saat latihan bersama dengan divisi lain maksimalkan ingatan dan jangan lupa senyum.

Pemain: Baik, kak.

Tindak tutur (3) dan (4) merupakan tindak tutur berbentuk memohon yang dilakukan oleh pelatih drum corps kepada pemain. Pada tindak tutur (3), pelatih meminta dengan halus kepada pemain yang bertanya agar menunggu penjelasan pelatih setelah waktu istirahat usai. Tuturan (3) terjadi ketika seorang pemain bertanya kepada pelatih untuk mencontohkan kembali gerakan melempar flag/Tos. Penanda tindak tutur memohon (3) adalah bentuk 'Saya jelaskan'.

Tindak tutur (4) dilakukan pelatih agar pemain tidak lupa senyum dan koreografi saat latihan bersama dengan divisi lain. Tuturan (4) terjadi setelah latihan pada divisi CG selesai dan hendak latihan gabungan semua divisi.
Penanda tindak tutur memohon (4) adalah bentuk 'Saya minta,'.

Pada penelitian sebelumnya yang dilakukan Putri (2015) mengungkapkan bahwa bentuk memohon merupakan bentuk yang digunakan mitra tutur melakukan hal yang disebutkan dalam tindak tutur yang dilakukan penutur. Oleh karena itu, penelitian ini melengkapi hasil penelitian sebelumnya.

\section{c. Tindak Tutur Direktif Bentuk Menyarankan}

Menurut Ibrahim (dalam Yahya, 2013: 22) fungsi menyarankan dalam tindak tutur direktif termasuk ke dalam fungsi nasihat (advisories). Teori tersebut bertentangan dengan teori Searle. Fungsi menyarankan pada tindak tutur direktif berguna untuk mengekspresikan pemberian saran atau anjuran yang bersifat kritis.

Pada latihan rutin SKDCU, pelatih divisi CG sering menggunakan tindak tutur direktif bentuk memohon. Bentuk tuturan menyarankan digunakan pelatih untuk memerintah penutur untuk bertindak atau melakukan hal berdasarkan pendapat pelatih. Tindak tutur direktif pelatih berbentuk menyarankan dalam latihan drum corps di SKDCU divisi CG dapat dilihat pada contoh berikut.

(5) Pelatih: Dibiasakan senyum ya, supaya saat tampil nggak kaku senyumnya. Pemain: (senyum)

(6) Pelatih: Jangan sampai flag-nya terinjak. Mark time jangan terlalu tinggi, jadi flag-nya tidak terinjak. Pemain: (memainkan koreografi)

Tindak tutur (5) dan (6) merupakan tindak tutur berbentuk menyarankan yang dilakukan oleh pelatih drum corps kepada pemain. Pada tindak tutur (5), pelatih menginstruksikan pemain agar tetap tersenyum ketika memainkan koreografi. Tuturan (5) terjadi ketika 
banyak pemain yang lupa senyum ketika memainkan koreografi. Penanda tindak tutur menyarankan (5) adalah bentuk 'supaya saat tampil nggak kaku senyumnya'.

Tindak tutur (6) dilakukan pelatih agar pemain memperhatikan langkah kaki ketika jalan ditempat/Mark time. Tuturan (6) terjadi ketika pelatih melihat seorang pemain menginjak flag saat memainkan koreografi. Penanda tindak tutur memohon (6) adalah bentuk 'Jangan sampai flag-nya terinjak' .

Terdapat persamaan dengan penelitian sebelumnya yang dilakukan Prawita (2020) yang mengungkapkan tiga bentuk tindak tutur direktif menyarankan dalam saluran youtube Mata Najwa. Wujud tindak tutur direktif menyarankan dibuktikan dengan mitra tutur yang melakukan hal yang disarankan penutur.

\section{d. Tindak Tutur Direktif Bentuk Menantang}

Menurut Prayitno (dalam Ardiawanto, 2016: 3) tindak tutur menantang berdasarkan teori tersebut termasuk dalam tipe mengajak. Prayitno mengategorikan tindak tutur direktif menjadi enam kategori sebagai berikut. 1) Tipe memerintah (to order). 2) Tipe meminta. 3) Tipe mengajak (to invite). 4) Tipe memberi nasihat (to advice). 5) Tipe mengkritik (to critic). 6) Tipe melarang (to prohibit). Tipe mengajak meliputi mengajak, membujuk, merayu, mendorong, mendukung, mendesak, menuntut, menantang, menagih, menargetkan.

Dalam latihan rutin SKDCU, tindak tutur menantang digunakan pelatih untuk memotivasi pemain dengan menyuruh pemain melakukan hal atau sesuatu yang diinginkan pelatih. Tindak tutur direktif pelatih berbentuk menantang dalam latihan drum corps di SKDCU divisi CG dapat dilihat pada contoh berikut.
(7) Pelatih: Flag on up. Single tos. Yang flag-nya jatuh, push up lima kali.

Pemain: Baik, kak.

(8) Pelatih: Kamu. Setelah windmill dalam, gerakan selanjutnya apa?

Pemain: Windmill luar, kak.

Tindak tutur (7) dan (8) merupakan tindak tutur berbentuk menantang yang dilakukan oleh pelatih drum corps kepada pemain. Pada tindak tutur (7), pelatih menantang pemain untuk melakukan gerakan melempar flag ke udara/Tos tanpa menjatuhkan flag ke tanah. Tindak tutur (7) terjadi ketika banyak pemain yang belum bisa melakukan gerakan melempar flag/Tos, sehingga pelatih menantang pemain untuk memotivasi pemain. Penanda tindak tutur menantang (7) adalah bentuk 'Yang flag-nya jatuh, push up lima kali'.

Tindak tutur (8) dilakukan pelatih agar pemain dapat mengingat urutan gerakan yang membentuk sebuah koreografi. Tindak tutur (8) terjadi ketika seorang pemain lupa terhadap koreografi, sehingga pelatih menunjuk dan menantang pemain tersebut dan menantang dengan tujuan untuk memotivasi pemain. Penanda tindak tutur menantang (8) adalah bentuk 'Setelah windmill dalam, gerakan selanjutnya apa?'.

Penelitian ini sesuai dengan hasil penelitian sebelumnya. Pada penelitian sebelumnya yang dilakukan Widyastuti (2020) mengungkapkan bentuk tindak tutur direktif menantang dalam saluran youtube Kisah Tanah Jawa. Tuturan Om Hao dalam video memberikan efek tertantang bagi para pemirsa saluran tersebut.

\section{SIMPULAN}

Analisis data yang dihasilkan dan dibahas menunjukkan adanya tindak tutur direktif pelatih drum corps divisi CG yang digunakan 
selama latihan rutin di SKDCU. Bentuk tindak tutur pada penelitian ini diklasifikasikan berdasarkan teori Searle mengenai tindak tutur direktif. Tindak tutur direktif yang digunakan antara lain, memerintah, memohon, menyarankan, dan menantang. Pada penelitian ini, tidak ditemukan tindak tutur direktif bentuk menasihati. Dapat diketahui bentuk tindak tutur yang sering digunakan adalah tindak tutur bentuk memerintah. Bentuk tindak tutur yang jarang digunakan adalah tindak tutur bentuk memohon. Bentuk tindak tutur memerintah dikenali dengan penanda ambil dan perhatikan baik-baik. Bentuk tindak tutur memohon dikenali dengan penanda saya jelaskan dan saya minta. Bentuk tindak tutur menyarankan dikenali dengan penanda supaya dan jangan sampai. Bentuk tindak tutur menantang dikenali dengan penanda push up lima kali dan gerakan selanjutnya apa?

Berdasarkan hasil penelitian beserta simpulannya, terdapat beberapa saran untuk pelatih. Pelatih diharapkan menggunakan tindak tutur yang beragam, tidak hanya tindak tutur direktif saja yang mendominasi latihan rutin drum corps, sehingga pelatihan berjalan lebih menyenangkan, tidak membuat pemain bosan, dan terjadi peristiwa tutur yang multiarah. Selain itu, penelitian ini dapat dijadikan sarana informasi bagi pelatih drum corps. Peneliti berharap penelitian ini dapat digunakan sebagai referensi penelitian yang berkaitan dengan tindak tutur. Peneliti juga berharap penelitian ini dapat mengedukasi dan bermanfaat bagi masyarakat.

\section{UCAPAN TERIMA KASIH}

Terima kasih kepada ketua Sabda Kinnara Drum Corps UNNES (SKDCU) atas izin yang diberikan kepada penulis untuk melakukan observasi; Pak Asep yang telah membimbing dan mendorong mahasiswanya untuk berkarya; dan Yessinta Yulianti serta Anindya Prawita yang telah memberi kritik dan saran terhadap penelitian ini.

\section{DAFTAR PUSTAKA}

Adawiyah, R. (2018). Tindak Tutur Direktif Guru Bahasa Indonesia dalam Penanaman Karakter Siswa Kelas VII SMP Muhammadiyah 3 Kepanjen Malang. Skripsi. University of Muhammadiyah Malang. Diunduh dari http://eprints.umm.ac.id/37534/.

Ardianto. (2013). Tindak Tutur Direktif Guru dalam Wacana Interaksi Kelas Anak Tunarungu. Jurnal Litera, No. 1 Vol. 12. Diunduh dari https://journal.uny.ac.id/index.php/litera/article/view/1318/1096.

Ardiawanto, HA., Ngalim, A. (2016). Tindak Tutur Direktif Guru Bahasa Indonesia Kelas VII B SMP Muhammadiyah 10 Surakarta dalam Proses Pembelajaran. Skripsi. Universitas Muhammadiyah Surakarta. Diunduh dari http://eprints.ums.ac.id/45249/30/NASKAH\%20\%20PUBLIKASI.pdf.

Arifiany, N., Ratna, M., Trahutami, S. (2016). Pemaknaan Tindak Tutur Direktif Dalam Komik "Yowamushi Pedal Chapter 87-93". Jurnal Japanese Literature, No. 1 Vol. 2. Diunduh dari https://ejournal3.undip.ac.id/index.php/japliterature/article/view/12522. 
Ariyani, S. (2017). Bentuk dan Fungsi Tindak Tutur Direktif dalam Prosespembelajaran Bahasa Indonesia. Skripsi. Universitas Muhammadiyah Surakarta. Diunduh dari http://eprints.ums.ac.id/54410/11/NASKAH\%20PUBLIKASI\%20BARU.pdf.

Darwis, A. (2019). Tindak Tutur Direktif Guru di Lingkungan SMP Negeri 19 Palu: Kajian Pragmatik. Jurnal Bahasa dan Sastra, No. 2 Vol. 4.

Elmita, W., Ermanto, Ratna, E. (2013). Tindak Tutur Direktif Guru Dalam Proses Belajar Mengajar Di TK Nusa Indah Banuaran Padang. Jurnal Pendidikan Bahasa Indonesia, No. 2 Vol. 1. Diunduh dari http://ejournal.unp.ac.id/index.php/pbs/article/view/1301/1128.

Harahap, AB. (2012). Selayang Pandang Seni Marching Band. Jurnal Bahas (Bahasa Sastra, Seni dan Budaya), No. 84 TH. 38. Diunduh dari https://jurnal.unimed.ac.id/2012/index.php/bahas/article/view/2335/2036.

Muhammad. (2011). Metode Penelitian Bahasa. Yogyakarta: Ar-Ruzz Media.

Mulyani. (2015). Kajian Pragmatik Terhadap Tindak Tutur Direktif Guru SMA dalam Kegiatan Belajar Mengajar di Kelas. Prosiding Prasasti. Diunduh dari https://jurnal.uns.ac.id/prosidingprasasti/article/view/85.

Nawawi, dkk. (2017). KETERAMPILAN BERBICARA Sebagai Suatu Keterampilan Berbahasa. Jakarta: Uhamka Press.

Prayekti, EP. (2015). Tindak Tutur Direktif Guru Dalam Pembelajaran Bahasa Indonesia Kelas IX SMP ISLAM AL HIKMAH JEMBER. Skripsi. Universitas Jember. Diunduh dari http://repository.unej.ac.id/handle/123456789/63556.

Prawita, A., Asep, PYU. (2020). Analysis of Directive Speech Acts in Mata Najwa Youtube Channel "Because of Corona: Why Indonesia Is Not Like Singapore". Jurnal Aksis, No. 1 Vol. 4. Diunduh dari http://journal.unj.ac.id/unj/index.php/aksis/article/view/15380.

Putri, FR. (2016). Tindak Tutur Direktif Guru Pada Pembelajaran Bahasa Indonesia Sma Negeri 15 Padang No. Bentuk Tindak Tutur Direktif. Jurnal Ekotrans, 16 (1). 15-36. Diunduh dari http://repo.stkip-pgri-sumbar.ac.id/id/eprint/3833.

Raditya, R. (2014). Fungsi Tindak Tutur Ilokusi Direktif Dalam Film Final Fantasy Vii Advent Children: Complete. Jurnal Ilmiah Mahasiswa Bahasa dan Sastra FIB (Jimbastra), No. 4 Vol. 5. Diunduh dari http://jimbastrafib.studentjournal.ub.ac.id/index.php/jimbastrafib/article/view/483.

Ramadhani, AD., Wahyudin, A. (2019). Analisis Tindak Tutur Direktif dalam Akun Twitter @ Sbyudhoyono. Jurnal Bahasa dan Sastra Indonesia, No 4 Vol 8. Diunduh dari http://journal.student.uny.ac.id/ojs/index.php/bsi/article/view/16720/16168.

Rustono. (1999). Pokok-Pokok Pragmatik. Semarang: IKIP Semarang Press. 
Qomariyah, L. (2017). Tentang Tindak Tutur Direktif Guru Dalam Pembelajaran Bahasa Arab. Journal of Arabic Studies, No. 1 Vol. 2. Diunduh dari http://journal.imla.or.id/index.php/arabi/article/view/32.

Sumarsih, N. (2018). Strategi dan Fungsi Tindak Tutur Direktif dalam Poster Pendidikan (Strategy and Function of Directive Speech Act in Educational Poster). Widyaparwa (Jurnal Ilmiah Kebahasaan dan Kesastraan), No. 1 Vol. 46. Diunduh dari http://garuda.ristekbrin.go.id/documents/detail/954060.

Syah, Nur Aini. (2017). Kesantunan Tindak Tutur Direktif dalam Talk Show Satu Jam Lebih Dekat Di TVOne (Tinjauan Pragmatik). Jurnal Adabiyyāt, No.1 Vol. 1. Diunduh dari http://ejournal.uin-suka.ac.id/adab/Adabiyyat/article/view/01105.

Waljinah, S., dkk. (2019). Tindak Tutur Direktif Wacana Berita Online: Kajian Media Pembelajaran Berbasis Teknologi Digital. Jurnal Sebasa, No. 2 Vol. 2. Diunduh dari http://e-journal.hamzanwadi.ac.id/index.php/sbs/article/view/1590.

Widyastuti, I., Asep, PYU. (2020). Tindak Tutur Direktif, Ekspresif, Deklarasi Dalam Video Channel Youtube 'Kisah Tanah Jawa' Pada Episode Gerbang Antar Dimensi. Jurnal Logat, No. 1 Vol. 7. Diunduh dari http://ejournal.fkip.unsri.ac.id/index.php/logat/article/view/307.

Yahya, IK. (2013). Tindak Tutur Direktif dalam Interaksi Belajar Mengajar Mata Pelajaran Bahasa dan Sastra Indonesia di SMA Negeri 1 Mlati Sleman Yogyakarta. Skripsi. Universitas Negeri Yogyakarta. Diunduh dari http://eprints.uny.ac.id/23286/1/Iwan\%20Khairi\%20Yahya\%2008201244053.pdf.

Yule, G. (2006). Pragmatik. Yogyakarta: Pustaka Pelajar.

Yuliarti, Y., Rustono, R. Nuryatin, A. (2015). Tindak Tutur Direktif dalam Wacana Novel Trilogi Karya Agustinus Wibowo. Jurnal Seloka, No. 2 Vol. 4. Diunduh dari https://journal.unnes.ac.id/sju/index.php/seloka/article/view/9864. 